\title{
9
}

\section{Affect, Emotions, and Feelings}

\author{
Donya Alinejad and Domitilla Olivieri
}

\section{Introduction}

In research on transnational migration, the role of emotions has generally remained understudied. Understanding emotions has largely been treated as secondary to studying the 'rational' economic factors that influence mobility. A valuable body of work has been developed around matters of migrant (non-) belonging, sense of home, and everyday life, primarily through qualitative research approaches. Still, few have studied these questions of identity and belonging in terms of emotion and feeling explicitly (Wood and Waite, 2011). It has been compellingly argued that we cannot properly understand migration phenomena without studying emotional and affective experiences as integral to migrancy, and indeed to social life (Baldassar, 2008; Conradson and McKay, 2007; Skrbiš, 2008; Svašek, 2008, 2010; Wise and Chapman, 2005). This argument challenges the wider emotionality-rationality split upon which the historical omission of emotion from the realm of social theorization is implicitly based (see also Reckwitz, 2012). Yet, there remains a gap between emotion studies and migration studies (Boccagni and Baldassar, 2015). Closing this gap has the potential to reveal the important emotional layers that migration inherently entails, thus extending the focus of research on emotion beyond notions of identity and belonging alone. It may sensitize us to the emotional facets of the economic and 
political factors that influence mobility, inviting closer understandings of how emotions are related to other spheres of migrant life. ${ }^{1}$

Important contributions have embedded globalization and transnational migration phenomena within theoretical debates around emotion, and these have tended towards approaches to emotion from anthropology and human geography that understand emotions as socially and culturally constructed (Boccagni and Baldassar, 2015; Svašek and Skrbiš, 2007). However, as new materialist approaches to the body became more current in the humanities and the 'affective turn' gained credence among some scholars within media and cultural studies, discussions of feelings and migrant subjects came to be theoretically framed, by some, in terms of affect (Cole and Groes, 2016). Broadly speaking, such conceptualizations differ from perspectives on emotion as a social construction, in that they are more ambiguous about the relation of human feelings to the social world. As a variety of communications technologies become involved in the expressions and experiences of emotion in transnational migration contexts, scholars across different disciplines and fields have shown increasing interest in the role of media in the emotional facets of migration. This complicates the task of embedding studies of migrant emotions within theoretical debates about emotion and affect. Nevertheless, in this chapter, we present a crossdisciplinary overview of some central discussions of emotion and affect in contexts of migrancy and media ubiquity, tracing some of the divergences and convergences within the current work on emotional and affective mediated connections and transnational migration. Based on the latest scholarship, we also identify a research direction that we find particularly productive when it comes to giving affect and emotion an important place in the discussion of migration and contemporary media practices. 


\section{Migrant emotions in a changing media landscape}

A variety of media forms have played a demonstrable role in the ways people feel emotions via transnational communications. Media are implicated in how people maintain relationships, produce subjectivities, and build communities under a range of conditions of mobility (and immobility). These media forms range from literary novels (e.g. Skrbiš, 2008) and telecommunications to communications that are not always thought of in terms of media, such as the sending and receiving of packages and remittances (e.g. Mckay, 2007). As communications technologies continue to develop and multiply, new questions arise as to the changing role of media in how emotion is conveyed and felt in various contexts of transnational mobility. Research focusing on media practices around film and television has been complementary to the work on emotion in migration studies. It has focused, for instance, on how the emotional dimensions of migrants' long-distance relationships to the 'homeland' are shaped through media products, practices, and discourses that produce experiences of diasporic memory and exile (e.g. Desai, 2004; Naficy, 1993, 1998). Cinema in particular has been studied in terms of its engagement with affect, emotion, and the bodily senses, showing how they contribute to creating spaces where identities and identification become possible, diasporic subjectivities take shape, and migrant memories are shared through media (Marks, 2000; Naficy, 2001). These studies have brought to the fore the necessity of focusing on the multisensory dimensions of exilic and diasporic films, both in terms of their technological materiality and in the (related) viewing experience they enable. This suggests that affect and emotion are inextricably linked with embodied and sensorial relations to media and technologies, as well as to the physical spaces in which people engage in practices of media production and consumption (Baym, 2010; Pink, 2009; Rodaway, 2011). 
Hence, media forms have long been a constitutive force in how the various life circumstances surrounding migration are communicated, represented, and experienced emotionally. As media technologies change and develop, and media practices around digital media forms tend more towards users and usage (or 'produsers' and 'produsage' (Bird, 2011)), new circumstances arise regarding which emotions are communicated, with what frequency, and to/by whom. This call for further investigation of how the materiality of diversifying digital-software formats and mobile devices mediate emotions in various migration contexts. It also has important implications for what kinds of migrant subjectivities, communities, and experiences of connection and intimate relation are produced through the particular sensory experiences afforded by emergent media practices such as mobile, app-based communications. The rise of Web 2.0 in particular has generated heightened scholarly attention for debates concerning how new technologies offer migrants possibilities for living their social lives transnationally (Alinejad, 2017). Internet-studies scholarship and ethnographic research on digital media in particular have investigated the emotional dimensions of intimate migrant relationships maintained and developed via web applications (Baldassar et al., 2016; Leurs, 2014; Madianou and Miller, 2012; Nedelcu, 2012; Wilding, 2006). Primarily, the focus in this work has been on how digital communications mediate emotional intimacy within transnational family relationships. The interest in intimacy also parallels a more general growing interest in social media and how platforms mediate intimate social relationships in emergent ways (Andreassen, 2017; Baym, 2010; Turkle, 2011; van Dijck, 2013). This work on the specificities of social media platforms implies a need for a better understanding of how specific social media platforms work. But anthropological research on social media has convincingly argued how specific platforms are taken up within local usage 
contexts alongside and in relation to the other apps and media forms people use (Miller et al., 2016). This is important if we want to engage with the question of which emotions are mediated more (or less) effectively by which apps, under which circumstances of mobility, and within which cultural contexts of social media use. These are questions that appear integral to the study of how contemporary transnational relationships, and the transnational social spaces in which intimacy takes place, are (re)produced.

\section{Mediating transnational intimacy and the politics of}

\section{emotion}

Within the work on migrant emotions, there are focal points evident around the experience of specific emotions related to migration. To give a brief overview, this includes discussions of shifting feelings of hope about migration and how they change as a result of experiences of migrant re-settlement (Raffaetà, 2015), or how feelings of fear and shame among forced migrants affect how they connect with others after migration (Witteborn, 2014). We also see how conditions of transnational migrancy have significant potential to reveal how the spatiality and temporality of emotion work through people's attachments to localities and places (Ahmed et al., 2003; Gallo, 2015; Kokanović and Božić-Vrbančić, 2015). Moreover, there are also important 'sensuous and affective dimensions' to cultural adaptation, mixing, and encounters with cultural difference that emerge in multicultural societies as a result of migration (Wise and Chapman, 2005; Wise and Velayutham, 2009). Hence, it is evident that migration is emotionally charged in a variety of ways. These include migrants' own emotional responses to experiences of mobility and communication across distance and absence, but also the wider resonances experienced, imagined, 
represented, and engaged with emotionally because of the collective presence of migrants.

One important strain of research related to media emerging in the literature on emotion and transnational migration, concerns long-distance intimate relationships. This includes debates about experiences of co-presence as part of intimate emotional relationships among migrants and those they leave behind. The notion of 'ambient virtual co-presence' was first coined to discuss how experiences of co-presence change, subject to the intensity of mobile device usage within these close emotional relationships (Itō et al., 2005). Since then, with the rise of social media platforms like Facebook, the notion of 'ambient co-presence' has been proposed to understand how experiences of emotional proximity are felt in specific ways through social media newsfeeds among family members (Madianou, 2016). This work challenges the claim that face-to-face, physical co-presence is the gold standard of experiencing intimate presence, with mediated forms of co-presence as lesser versions of the experience. Rather, it discusses digital media as affording feelings of co-presence that are an important part of equally intimate relationships (Nedelcu, 2012).

A different trend within the research on emotions and migration has pointed to the role of emotion within the political contexts of Western countries receiving migrants. For instance, Boccagni and Baldassar (2015: 74) have pointed out that the 'politics of fear and a rise in xenophobia has come to dominate most contemporary political campaigns whether at the level of small towns, nations or globally', and Ahmed (2004a) has analyzed how the love and anxiety of European xenophobic politics are powerfully at work in responses to mass migration. Ahmed is not alone in granting media an important role in emotional processes of self-other formation, arguing that the circulation of anxiety in an affective economy is what increases the 
emotional intensity and the value of certain images or narratives. Modest and de Koning (2016) also signal the rise of 'anxiety politics' in Europe, referring to the structures of feeling connected to the nation, enacted through both formal politics and mass media. Digital media research has also investigated the emotional responses in mass media coverage of particular images in the migrant crisis and how they circulate on social media (Aulich et al., 2015). While partial, this overview indicates that, overall, the work on migration and emotion/affect reflects both the wide-ranging analytical senses in which emotion and affect feature in the work on media and migration phenomena, but also how it implicates both 'homeland' contexts and 'host' country settings, as well as both intimate and public spheres of social and political life.

\section{Affective relations between mobile bodies and media}

\section{forms}

Over the course of at least the past ten years, scholars of affect have developed a framework for theorizing bodies and technologies as things that affect and are affected by one another within the assemblages that connect them to each other (for a critical overview see Gregg and Seigworth, 2010; Hillis et al., 2015; Leys, 2011; Papoulias and Callard, 2010). As previously mentioned, theories of affect have recently gained currency in the humanities, including media studies. Some of this work has tended to foreground the potentials of affect in terms of a 'turn' away from the discursive, 'cognitive', socially constructed, representational, semiotic, and linguistic, and a focus on assemblages, relationality, and the body/embodiment. In this sense, affect theory has emerged as a research field that proposes a diversity of ways in which affect - most often understood as a change in, or flow/circulation of, intensity - is differentially related to notions of emotion/feeling, language, and 
cognition (Ahmed, 2004b; Brennan, 2004; Deleuze and Guattari, 1987; Massumi, 2002; Sedgwick, 2003; Tomkins, 1995). For the body, this means that it does not engage with the world as the extension of a pre-existing subject that perceives the outside world through consciousness (Blackman, 2012; Karatzogianni and Kuntsman, 2012). Rather, the body is posited as always in the midst of human/non-human assemblages, in which objects also have certain forms of agency in acting upon it. For instance, within the field of critical media and technology studies, some scholars have investigated how affect works as part of online networks and digital assemblages (Karatzogianni and Kuntsman, 2012). While others have discussed the interaction between humans and technology, arguing that "media have become "infrastructures of intimacy", such that connections are now formed not only with other people, but with “devices, apps and platforms"” (Attwood et al., 2017: 2). In feminist media studies, there have also been interventions that rethink the limitations and political implications of the 'affective turn' by 'expanding on affect's conceptual, empirical, and political agenda' (Zarzycka and Olivieri, 2017: 530). Theorizing mediated affective encounters as online-offline assemblages is relevant for our discussion on affect, media, and migration, as it offers a framework for attending to 'the global/geopolitical and the local/everyday potentialities of affect' (ibid.: 529-30). Notwithstanding the variations between the arguments of scholars engaging with affect theory that we are not able to go into here, there tends to be a shared focus on theorizing the formation of subjectivities as they emerge through specific encounters that set off a process of being affected.

On the other hand, anthropological approaches to emotion have tended to focus on how emotions are socially constructed, emphasizing the need to situate our understanding of emotion within ideas of the social and with relation to the culturally 
specific context in which emotions are felt. However, some scholars have pointed out the challenges of studying emotions within the relevant cultural interpretive frameworks when globalization, mobility, and variations of gender and sexuality complicate how cultural reproduction takes place (Boellstorff and Lindquist, 2004; Gammerl et al., 2017). This calls for an understanding of emotion that takes into account how circuits of migration are part of the transnational social fields that are formed through communication and the mobility of objects. Thinking of emotions as embedded within transnational social fields that are produced through circulations of people, things, and messages usefully posits emotions as social while also paying attention to the cultural dynamism and crossings that come with people's physical mobility between places as they position themselves with reference to particular cultural contexts. Moreover, some have argued for theorizing affect interculturally and cross-culturally (Boellstorff and Lindquist, 2004; Gammerl et al., 2017), as well as for theorizing local and internal variation of affective experiences and the role of sub-spaces for alternative affective encounters (Gammerl et al., 2017; McGlotten, 2013). Such approaches add complexity to discussions of emotion that are more concerned with normative cultural processes through which emotionality is socialized. They also open up questions around processes of being affected; why are some within the same cultural milieu affected differently than others? When does an affective transmission fail? And what does this tell us about how communities are affectively formed through media? There are elements of this debate evident in the different approaches to the digital mediation of emotion and affect in migrants' lives.

Some scholars emphasize how the introduction of digital technologies in particular has led to a reconfiguration of how migrants feel about their place in the world. Diminescu (2008: 572), for instance, has argued influentially that migrant life 
in an era of digital connections reflects more of an 'active and affective' character because of the sense of simultaneity/proximity that can be felt, especially through real-time digital communications. Other work has demonstrated how digital communications do not necessarily warrant an epistemological shift to our understanding of emotional relationships in migration settings, but reveal interesting ways of being taken up within the existing moral orders and media environments in which transnational emotional relationships are lived (Madianou and Miller, 2012). Paasonen et al. write that

[w]hen turning to affect, it is problematic - not to mention lacking in rigor to simply 'add affect' onto one's existing research agenda without addressing the broad set of ontological, epistemological, methodological and sociopolitical concerns and challenges that affect poses to one's conceptual and methodological practice. (Paasonen et al., 2015: 5)

However, it can be argued that the need for such shifts is dependent upon how emotion and affect are understood and conceptualised in the first place. Spatially sensitive approaches to mobile, mediated emotion have challenged the need for such a shift. Recent work that highlights the socio-spatial dimensions of emotional circulation is particularly interesting for doing research on affect and emotion. Navaro-Yashin's (2009) important argument that emotion both circulates and is rooted, without one process negating the other, is one such contribution. This perspective rejects the proposed paradigm shift represented by Deleuzian theories of affect that have gained currency as part of the 'affective turn' within the humanities, demonstrating instead the continuities between discursive and embodied modes of understanding emotion when studied through ethnographic methods. This is presented as an argument against positing the rhizomatic circulation of affect in opposition to 
the rootedness of emotion in material sites. Its critique of affect theory also has parallels to how Boellstorff and Lindquist (2004) problematized the earlier tendency to appeal to 'the body' as pre-social and thus a panacea to the problem of understanding emotion through social constructivism in culturally diverse sociocultural contexts destabilized by globalization.

Feminist scholarship has also contributed to this spatial approach to affect and emotion, evident in recent work that argues 'space-sensitive approaches' facilitate the bringing together of meaning at the level of semiotics and culture with the level of viscerality and physiology (Gammerl et al., 2017). This focus on spatiality has yielded understandings of emotion that engage with affect theory's subject-object 'assemblages' - which produce contingent affective outcomes - while at the same time reading the meanings of these assemblages in terms of the specific political and historical circumstances in which they take shape. These examples of work focusing on spatiality are not the only ones that closely relate the study of discursive and social practices to sensorial and embodied affective experiences. However, the spatial focus seems particularly applicable for the study of migration and media due to the significance of space as a site for understanding the social implications of circuits of human (im)mobility and communication. Ethnographic contributions to the study of spatially mobile media practices have demonstrated how a spatially situated approach to media forms is effective, including in migration contexts (Hjorth and Lim, 2012; Postill and Pink, 2012; Zijlstra and Liempt, 2017). In turn, studying emotional mediation through migration experiences has the potential to reveal important spatial dynamics of emotional experience. This also releases emotion and affect from being limited to the realm of individual, internal states and rather builds on analyses of emotion and affect acknowledging the politics of how bodies are affected and 
sensitized to feeling in certain ways. For instance, in accordance with regimes of mobility, bodily practice, and discipline, as well as through sense memories of places of one's past dwelling, or collectively shared experiences of media.

\section{Conclusions}

Through an outline of some of the current contentions around the discussion of how affect and emotion are mediated in contexts of transnational migration, we have aimed to demonstrate the potentials of being more sensitive to space. It allows us to research affect and emotion through ethnographic methodological approaches that have underpinned the qualitative study of translocal migratory life characterized by everyday routines, meaningful rituals, and a range of emotional, media, and cultural practices together. When taking into account the methodological challenges of working with digital media and affect, it is noticeable that strains of work engaging with current notions of affect acknowledge the productivity of integrating languagebased and affective analysis in the study of digital media (Hillis et al., 2015; Karatzogianni and Kuntsman, 2012). Indeed, methodological questions of how to access affect in relation to media usages, technologies, and objects are in practice answered most often with (calls for) research practices oriented towards cultivating and reflecting upon the researcher's sensitivities to affective and emotional resonances and registers when conducting ethnographic research through interviews and participant observation approaches. Such methodological approaches to studying affect empirically largely rely on integrating embodied and sensory engagement, with an attunement to the environment in which the research is being conducted (Pink, 2009; Pink et al., 2016), and with the textual analysis of field-notes and interview responses. They also build upon work on 'sensuous geographies' (McKay, 2005) and on the affective articulation of bodies in specific migration cases (Wise and Chapman, 
2005). At the current juncture, these spatially sensitive approaches become particularly productive in offering ways forward in the study of affect and mediated emotions in migration contexts, especially when combined with a critical awareness of conceptual debates concerning media materiality, subjectivities, and communities, and with ethnographic methodologies that focus on sensorial and affective experience.

\section{Notes}

${ }^{1}$ See also the literature problematizing the separation of the study of emotions from the political, pointing out the need to see emotions as integral to political processes, rather than viewing emotion primarily as a force rallied up to the detriment of rational political engagement. This has built on arguments by anthropologists in seminal works (C. Lutz, 1986; C. A. Lutz and Abu-Lughod, 1990), which situate dominant scholarly understandings of emotion in terms of Western knowledge production (which conceive of emotions as the opposite of rationality, noting that this opposition is, itself, culturally specific and ideologically laden).

\section{Acknowledgments}

Part of the research for this chapter was done with financial support of the ERC (European Research Council) consolidator grant 'Digital crossings in Europe: Gender, diaspora and belonging' (CONNECTINGEUROPE), grant 647737.

\section{References}

Ahmed, S. (2004a). Affective economies. Social Text, 22(2), 117-139.

Ahmed, S. (2004b). The cultural politics of emotion. New York, NY: Routledge. 
Ahmed, S., Castada, C., Fortier, A.-M., \& Sheller, M. (Eds.). (2003). Uprootings/regroundings: Questions of home and migration. Oxford, UK: Berg Publishers.

Alinejad, D. (2017). The internet and formations of Iranian American-ness: Next generation diaspora. Cham, Switzerland: Palgrave Macmillan, Springer International Publishing AG.

Andreassen, R. (2017). New kinships, new family formations and negotiations of intimacy via social media sites. Journal of Gender Studies, 1-11. https://doi.org/10.1080/09589236.2017.1287683

Aulich, J. et al. (2015, November 1). The Iconic Image on Social Media: A Rapid Response to the Death of Aylan Kurdi. visualsocialmedialab.org. Retrieved June 18, 2018, from http://visualsocialmedialab.org/blog/the-iconic-image-on-social-media-arapid-response-to-the-death-of-aylan-kurdi

Attwood, F., Hakim, J., \& Winch, A. (2017). Mediated intimacies: Bodies, technologies and relationships. Journal of Gender Studies, 1-5. https://doi.org/10.1080/09589236.2017.1297888

Baldassar, L. (2008). Missing kin and longing to be together: Emotions and the construction of co-presence in transnational relationships. Journal of Intercultural Studies, 29(3), 247-266. https://doi.org/10.1080/07256860802169196

Baldassar, L., Nedelcu, M., Merla, L., \& Wilding, R. (2016). ICT-based co-presence in transnational families and communities: Challenging the premise of face-to-face proximity in sustaining relationships. Global Networks, 16(2), 133-144. https://doi.org/10.1111/glob.12108 
Baym. N. (2010). Personal connections in the digital age. Malden, MA: Polity Press.

Bird, S. E. (2011). Are we all produsers now? Convergence and media audience practices. Cultural Studies, 25(4-5). https://doi.org/10.1080/09502386.2011.600532

Blackman, L. (2012). Immaterial bodies: Affect, embodiment, mediation (Google $\begin{array}{llll}\text { eBook). } & \text { SAGE. } & \text { Retrieved }\end{array}$ http://books.google.com/books?id=hKQhghhRamIC\&pgis=1

Boccagni, P., \& Baldassar, L. (2015). Emotions on the move: Mapping the emergent field of emotion and migration. Emotion, Space and Society, 16, 73-80. https://doi.org/10.1016/j.emospa.2015.06.009

Boellstorff, T., \& Lindquist, J. (2004). Bodies of emotion: Rethinking culture and emotion through Southeast Asia. Ethnos, 69(4), 437-444. https://doi.org/10.1080/0014184042000302290

Brennan, T. (2004). The transmission of affect. Ithaca, NY: Cornell University Press. Retrieved from http://public.eblib.com/choice/publicfullrecord.aspx?p=3138638

Cole, J., \& Groes, C. (2016). Affective circuits: African migrations to Europe and the pursuit of social regeneration. Chicago: University of Chicago Press.

Conradson, D., \& McKay, D. (2007). Translocal subjectivities: Mobility, connection, emotion. Mobilities, 2(2), 167-174. https://doi.org/10.1080/17450100701381524

Deleuze, G., \& Guattari, F. (1987). A thousand plateaus: Capitalism and schizophrenia. Minneapolis, MN: University of Minnesota Press. 
Desai, J. (2004). Beyond Bollywood: The cultural politics of South Asian diasporic film. Psychology Press. New York and London

Diminescu, D. (2008). The connected migrant: An epistemological manifesto. Social Science Information, 47(4), 565-579. https://doi.org/10.1177/0539018408096447

Gallo, E. (2015). The irony of kinship migration and the control of emotions among Malayalis. Emotion, Space and Society, 16, 108-115. https://doi.org/10.1016/j.emospa.2014.12.001

Gammerl, B., Hutta, J. S., \& Scheer, M. (2017). Feeling differently: Approaches and their politics. Emotion, Space and Society, 25, 87-94. https://doi.org/10.1016/j.emospa.2017.07.007

Gregg, M., \& Seigworth, G. J. (Eds). (2010). The affect theory reader. Durham, NC: Duke University Press Books.

Hillis, K., Paasonen, S., \& Petit, M. (2015). Networked affect. Cambridge, MA; London, UK: MIT.

Hjorth, L., \& Lim, S. S. (2012). Mobile intimacy in an age of affective mobile media. $\begin{array}{llll}\text { Feminist } & \text { Media } & \text { Studies, } & \text { 12(4), }\end{array}$ https://doi.org/10.1080/14680777.2012.741860

Itō, M., Okabe, D., \& Matsuda, M. (2005). Personal, portable, pedestrian: Mobile phones in Japanese life. Cambridge, MA: MIT Press.

Karatzogianni, A., \& Kuntsman, A. (2012). Digital cultures and the politics of emotion: Feelings, affect and technological change. New York, NY: Palgrave Macmillan. 
Kokanović, R., \& Božić-Vrbančić, S. (2015). Being marked as different: The emotional politics of experiences of depression and migrant belongings. Emotion, Space and Society, 16, 130-137. https://doi.org/10.1016/j.emospa.2014.07.002

Leurs, K. (2014). The politics of transnational affective capital: Digital connectivity among young Somalis stranded in Ethiopia. Crossings: Journal of Migration \& Culture, 5(1), 87-104. https://doi.org/10.1386/cjmc.5.1.87_1

Leys, R. (2011). The turn to affect: A critique. Critical Inquiry, 37(3), 434-472. https://doi.org/10.1086/659353

Lutz, C. (1986). Emotion, thought, and estrangement: Emotion as a cultural category. Cultural Anthropology, 1(3), 287-309. https://doi.org/10.1525/can.1986.1.3.02a00020

Lutz, C. A., \& Abu-Lughod, L. (1990). Language and the politics of emotion. New York, NY: Cambridge University Press.

Madianou, M. (2016). Ambient co-presence: Transnational family practices in polymedia environments. Global Networks, 16(2), 183-201. https://doi.org/10.1111/glob.12105

Madianou, M., \& Miller, D. (2012). Migration and new media: Transnational families and polymedia. Abingdon, UK and New York, NY: Routledge.

Marks, L. U. (2000). The skin of the film : Intercultural cinema, embodiment, and the senses. Durham, NC: Duke University Press.

Massumi, B. (2002). Parables for the virtual: Movement, affect, sensation. Durham, NC: Duke University Press. 
McGlotten, S. (2013). Virtual intimacies: Media, affect, and queer sociality. Albany, NY: SUNY Press.

McKay, D. (2005). Migration and the sensuous geographies of re-emplacement in the Philippines. Journal of Intercultural Studies, 26(1-2), 75-91. https://doi.org/10.1080/07256860500074052

McKay, D. (2007). 'Sending dollars shows feeling' - Emotions and economies in Filipino migration. $\quad$ Mobilities, $\quad 2(2), \quad$ 175-194. https://doi.org/10.1080/17450100701381532

Miller, D., Costa, E., Haynes, N., McDonald, T., Nicolescu, R., Sinanan, J., ... Wang, X. (2016). How the world changed social media. London, UK: UCL Press. https://doi.org/10.14324/111.9781910634493

Modest, W., \& de Koning, A. (2016). Anxious politics in the European city: An introduction. Patterns of Prejudice, 50(2), 97-108. https://doi.org/10.1080/0031322X.2016.1161384

Naficy, H. (1993). The making of exile cultures: Iranian television in Los Angeles. Minneapolis, MN: University of Minnesota Press.

Naficy, H. (Ed.). (1998). Home, exile, homeland: Film, media, and the politics of place. New York, NY: Routledge.

Naficy, H. (2001). An accented cinema : Exilic and diasporic filmmaking. Princeton, NJ: Princeton University Press. 
Navaro-Yashin, Y. (2009). Affective spaces, melancholic objects: Ruination and the production of anthropological knowledge. Journal of the Royal Anthropological Institute, 15(1), 1-18. https://doi.org/10.1111/j.1467-9655.2008.01527.x

Nedelcu, M. (2012). Migrants' new transnational habitus: Rethinking migration through a cosmopolitan lens in the digital age. Journal of Ethnic and Migration Studies, 38(9), 1339-1356. https://doi.org/10.1080/1369183X.2012.698203

Paasonen, S., Hillis, K., \& Petit, M. (2015). Networks of transmission: Intensity, sensation, value. In Networked Affect. MIT Press.

Papoulias, C., \& Callard, F. (2010). Biology's gift: Interrogating the turn to affect. Body \& Society, 16(1), 29-56. https://doi.org/10.1177/1357034X09355231

Pink, S. (2009). Doing sensory ethnography. London; Thousand Oaks, CA: SAGE.

Pink, S., Horst, H., Postill, J., \& Hjorth, L. (2016). Digital ethnography: Principles and practice. Los Angeles, CA: SAGE.

Postill, J., \& Pink, S. (2012). Social media ethnography: The digital researcher in a messy web. Media International Australia, (145), 123-134.

Raffaetà, R. (2015). Hope emplaced. What happens to hope after arrival: The case of Ecuadorian families living in Italy. Emotion, Space and Society, 16, 116-122. https://doi.org/10.1016/j.emospa.2015.04.003

Reckwitz, A. (2012). Affective spaces: A praxeological outlook. Rethinking History, 16(2), 241-258. https://doi.org/10.1080/13642529.2012.681193 
Rodaway, P. (2011). Sensuous geographies: Body, sense and place. London, UK: Routledge.

Sedgwick, E. K. (2003). Touching feeling: Affect, pedagogy, performativity. Durham, NC; London, UK: Duke University Press.

Skrbiš, Z. (2008). Transnational families: Theorising migration, emotions and belonging. Journal of Intercultural Studies, 29(3), 231-246. https://doi.org/10.1080/07256860802169188

Svašek, M. (2008). Who cares? Families and feelings in movement. Journal of Intercultural Studies, 29(3), 213-230. https://doi.org/10.1080/07256860802169170

Svašek, M. (2010). On the move: Emotions and human mobility. Journal of Ethnic and Migration Studies, 36(6), 865-880. https://doi.org/10.1080/13691831003643322

Svašek, M., \& Skrbiš, Z. (2007). Passions and powers: Emotions and globalisation. Identities, 14(4), 367-383. https://doi.org/10.1080/10702890701578415

Tomkins, S. S. (1995). Exploring affect: The selected writings of Silvan S Tomkins. New York, NY: Cambridge University Press.

Turkle, S. (2011). Alone together: Why we expect more from technology and less from each other. New York, NY: Basic Books.

van Dijck, J. (2013). The culture of connectivity: A critical history of social media. Oxford, UK: Oxford University Press. 
Wilding, R. (2006). 'Virtual' intimacies? Families communicating across transnational contexts. Global Networks, 6(2), 125-142. https://doi.org/10.1111/j.1471-0374.2006.00137.x

Wise, A., \& Chapman, A. (2005). Introduction: Migration, affect and the senses. Journal of Intercultural Studies, 26(1-2), 1-3. https://doi.org/10.1080/07256860500074425

Wise, A., \& Velayutham, S. (2009). Everyday multiculturalism. Basingstoke, UK; New York, NY: Palgrave Macmillan.

Witteborn, S. (2014). Forced migrants, emotive practice and digital heterotopia. Crossings: Journal of Migration \& Culture, 5(1), 73-85. https://doi.org/10.1386/cjmc.5.1.73_1

Wood, N., \& Waite, L. (2011). Editorial: Scales of belonging. Emotion, Space and Society, 4(4), 201-202. https://doi.org/10.1016/j.emospa.2011.06.005

Zarzycka, M., \& Olivieri, D. (2017). Affective encounters: Tools of interruption for activist media practices. Feminist Media Studies, 17(4), 527-534. https://doi.org/10.1080/14680777.2017.1326546

Zijlstra, J., \& Liempt, I. V. (2017). Smart(phone) travelling: Understanding the use and impact of mobile technology on irregular migration journeys. International Journal of Migration and Border Studies, 3(2-3), 174-191. https://doi.org/10.1504/IJMBS.2017.083245 
